\title{
ChemComm
}

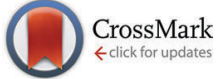

Cite this: Chem. Commun., 2016, 52, 4301

Received 29th November 2015 Accepted 23rd February 2016

DOI: $10.1039 / c 5 c c 09859 a$

www.rsc.org/chemcomm

\section{A novel dimethylformamide (DMF) free bar-cast method to deposit organolead perovskite thin films with improved stability $\dagger$}

\author{
Eurig W. Jones, ${ }^{a}$ Peter J. Holliman, ${ }^{* a}$ Arthur Connell, ${ }^{a}$ Matthew L. Davies, ${ }^{b}$ \\ Jennifer Baker, ${ }^{b}$ Robert J. Hobbs, ${ }^{a}$ Sanjay Ghosh, ${ }^{a}$ Leo Furnell, ${ }^{a}$ Rosie Anthony ${ }^{a}$ \\ and Cameron Pleydell-Pearce
}

\begin{abstract}
We report a solvent-free approach to synthesizing organolead perovskites by using solid state reactions to coat perovskite crystals onto $\mathrm{Al}_{2} \mathrm{O}_{3}$ or $\mathrm{TiO}_{2}$ nanoparticles followed by addition of terpineol affording perovskite inks. We have bar cast these inks to produce photoactive perovskite thin films which are significantly more stable to humidity than solution-processed films. This new method also avoids the use of toxic DMF solvent.
\end{abstract}

Since the initial reports of organolead halide perovskite solar cells, ${ }^{1,2}$ device efficiencies have risen rapidly towards $20 \%{ }^{3}$ It has also been demonstrated that such perovskites work efficiently in a variety of PV device architectures ${ }^{4}$ including planar $\mathrm{TiO}_{2}$ charge collection layers ${ }^{5}$ and mesoporous $\mathrm{TiO}_{2}$ as well as in batteries ${ }^{6 a}$ and sensors. ${ }^{6 b}$ Electrically-insulating $\mathrm{Al}_{2} \mathrm{O}_{3}$ scaffolds $^{1}$ and even hole transporter-free perovskite devices ${ }^{7}$ have been reported, demonstrating that the perovskite absorber layer can efficiently sustain charge transport. This is important because key limiting factors for perovskite solar cells are the surface coverage and crystallisation steps which occur at the perovskite-metal oxide interface during device manufacture. As a result, perovskite device manufacturing is the subject of much interest. A current limitation for one-step, solution processed perovskites is infiltration into the mesoporous scaffold, which can be improved by sequential deposition, ${ }^{8}$ affording superior coverage and avoiding the need for a perovskite capping layer. However, concerns remain over the solvents used for solution processed perovskites ${ }^{9}$ and the stability of the resulting materials to temperature and/or moisture. ${ }^{10,11}$ As such, recent reports suggest optimum fabrication conditions such as $\% \mathrm{RH}<1 \%{ }^{10}$ which complicates scale up.

To date, the choice of perovskite processing solvent has been limited to dimethylformamide (DMF), ${ }^{1}$ dimethylsulfoxide

\footnotetext{
${ }^{a}$ School of Chemistry, Bangor University, Bangor, Gwynedd LL57 2UW, UK

${ }^{b}$ SPECIFIC, Swansea University, Swansea, SA1 8EN, UK.

E-mail: p.j.holliman@bangor.ac.uk

$\dagger$ Electronic supplementary information (ESI) available. See DOI: 10.1039/ c5cc09859a
}

(DMSO) $^{12}$ or $\gamma$-butyrolactone (GBL) ${ }^{2}$ given the need to dissolve the $\mathrm{PbX}_{2}$ precursor $(\mathrm{X}=\mathrm{Cl}, \mathrm{Br}, \mathrm{I})$. By comparison, methyl ammonium halides are readily soluble in most solvents including water. In this paper, we report that a 1:1 ratio of $\mathrm{PbX}_{2}$ and $\mathrm{CH}_{3} \mathrm{NH}_{3} \mathrm{X}$ react readily together with quantitative yield in solvent-free, solid state reactions by grinding/milling (ESI, $\dagger$ Fig. S1). We have also studied the addition of metal oxide nanoparticles $\left(\mathrm{Al}_{2} \mathrm{O}_{3}\right.$ or $\left.\mathrm{TiO}_{2}\right)$ as common scaffold materials for perovskite solar cells during or after the solid state perovskite reaction. After perovskite has formed on the metal oxide surface, to produce a printable ink, we have ground the particles in terpineol as a suspending media rather than a solvent. Perovskite crystals have previously been suspended in $\mathrm{DMF}^{12}$ but here terpineol has been chosen because it has low toxicity and is widely used in printing media. It also possesses a high boiling point $\left(219^{\circ} \mathrm{C}\right)$, which is similar to DMSO $\left(189^{\circ} \mathrm{C}\right)$ which has been reported to stabilise solvent- $\mathrm{PbI}_{2}$ complexes and inhibit $\mathrm{PbI}_{2}$ crystallization. ${ }^{13}$ This also avoids the DMF volatilisation (b.p. $153{ }^{\circ} \mathrm{C}$ ) during spin coating, which increases perovskite crystal dislocations. Higher boiling solvents also encourage slower perovskite crystal growth during annealing. The resultant inks can then be doctor bladed or bar cast. We have studied the influence of metal oxide loading and found that, for $\mathrm{Al}_{2} \mathrm{O}_{3}$, a loading of $>10 \% \mathrm{Al}_{2} \mathrm{O}_{3}$ is required to cast a uniform layer, presumably because $\mathrm{Al}_{2} \mathrm{O}_{3}$ acts as a plasticizer. This is more than the $5 \% \mathrm{Al}_{2} \mathrm{O}_{3}$ reported by Carnie et al. ${ }^{14}$ for their $\mathrm{DMF} /$ perovskite/ $\mathrm{Al}_{2} \mathrm{O}_{3}$ nanoparticle precursor in their spin coating based study. The difference is that the perovskite particles are pre-formed on the $\mathrm{Al}_{2} \mathrm{O}_{3}$ particle surfaces in our inks and no DMF is present unlike previous reports of bar-cast perovskites. ${ }^{15}$ Visual inspection also suggests that the resulting colloidal inks are stable for $>3$ months. An additional advantage of developing inks for meso-scopic perovskite solar cells using a passive $\mathrm{Al}_{2} \mathrm{O}_{3}$ scaffold is their lowtemperature processability. Thus, our inks can be deposited under ambient conditions and heated at $110{ }^{\circ} \mathrm{C}$ because high temperature processing is not required to ensure inter-particle "necking" to carry electrical charge as is the case for $\mathrm{TiO}_{2}$ photo-electrodes. ${ }^{16}$ This is in line with previous reports for $\mathrm{Al}_{2} \mathrm{O}_{3}$ where heat processing is shown 
to be complete at $150{ }^{\circ} \mathrm{C}^{17}$ and $110{ }^{\circ} \mathrm{C} .{ }^{14}$ The perovskite ink formation is described in eqn (1) and (2).

$$
\begin{aligned}
& {\left[\mathrm{PbX}_{2}+\mathrm{Al}_{2} \mathrm{O}_{3}\right]+\mathrm{CH}_{3} \mathrm{NH}_{3} \mathrm{X} \rightarrow\left[\mathrm{CH}_{3} \mathrm{NH}_{3} \mathrm{PbX}_{3}: \mathrm{Al}_{2} \mathrm{O}_{3}\right]} \\
& {\left[\mathrm{CH}_{3} \mathrm{NH}_{3} \mathrm{PbX}_{3}: \mathrm{Al}_{2} \mathrm{O}_{3}\right]+\text { terpineol } \rightarrow \text { Perovskite ink }}
\end{aligned}
$$

For film deposition, a compact $80 \mathrm{~nm} \mathrm{TiO}_{2}$ layer (Solaronix BL) was spin coated (3500 rpm, $60 \mathrm{~s})$ onto TEC15 glass $\left(15 \Omega \mathrm{sq}^{-1}\right.$, NSG) and heated $\left(550{ }^{\circ} \mathrm{C}\right.$ for $\left.1 \mathrm{~h}\right)$. Perovskite inks were deposited onto these substrates either by spin coating, doctor blading or bar casting to produce films ranging from $400 \mathrm{~nm}$ to $\mathrm{ca} .10 \mu \mathrm{m}$ in thickness. In addition, to drastically increasing the atom efficiency of the perovskite manufacturing process, the stoichiometric nature of these solid state reactions is key to improving the compositional control over the materials produced. Thus, in Snaith et al. original report of perovskite devices, ${ }^{1}$ a $3: 1$ ratio of $\mathrm{CH}_{3} \mathrm{NH}_{3} \mathrm{I}: \mathrm{PbCl}_{2}$ was used along with spin coating to control layer thickness. However, the $\mathrm{I}: \mathrm{Cl}$ ratio of the resultant $\mathrm{CH}_{3} \mathrm{NH}_{3} \mathrm{PbI}_{2} \mathrm{Cl}$ was reported as 2:1. Effectively, this means that an excess of $\mathrm{CH}_{3} \mathrm{NH}_{3} \mathrm{I}$ is required to convert all the $\mathrm{PbCl}_{2}$ into perovskite. Whilst $\mathrm{CH}_{3} \mathrm{NH}_{3} \mathrm{X}$ waste is less of an issue at the laboratory scale, it is not viable for a scaled process because it multiplies raw material costs and environmental impact which has been reported to be greater for $\mathrm{CH}_{3} \mathrm{NH}_{3} \mathrm{I}$ than for $\mathrm{PbX}_{2}{ }^{18}$ By comparison, in the solid state reactions, $\mathrm{CH}_{3} \mathrm{NH}_{3} \mathrm{X}$ and $\mathrm{PbX}_{2}$ can be reacted together in the desired ratio and this ratio is carried through into the resulting perovskite material. A further advantage of solid state reactions is much greater control of trace components (e.g. $\left.\mathrm{Cl}^{-}\right)$which is known to be key to device performance. ${ }^{19}$

To prepare organolead perovskites on $\mathrm{Al}_{2} \mathrm{O}_{3}, \mathrm{PbX}_{2}(\mathrm{X}=\mathrm{Cl}$, $\mathrm{Br}, \mathrm{I})$ and $\mathrm{Al}_{2} \mathrm{O}_{3}$ nanoparticles (mean size $13 \mathrm{~nm}$ ) are ground together until there is no further colour change. After adding the desired $\mathrm{CH}_{3} \mathrm{NH}_{3} \mathrm{X}$ to this the mixture is ground together

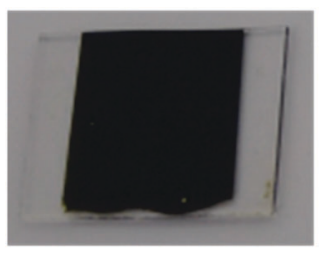

(a)
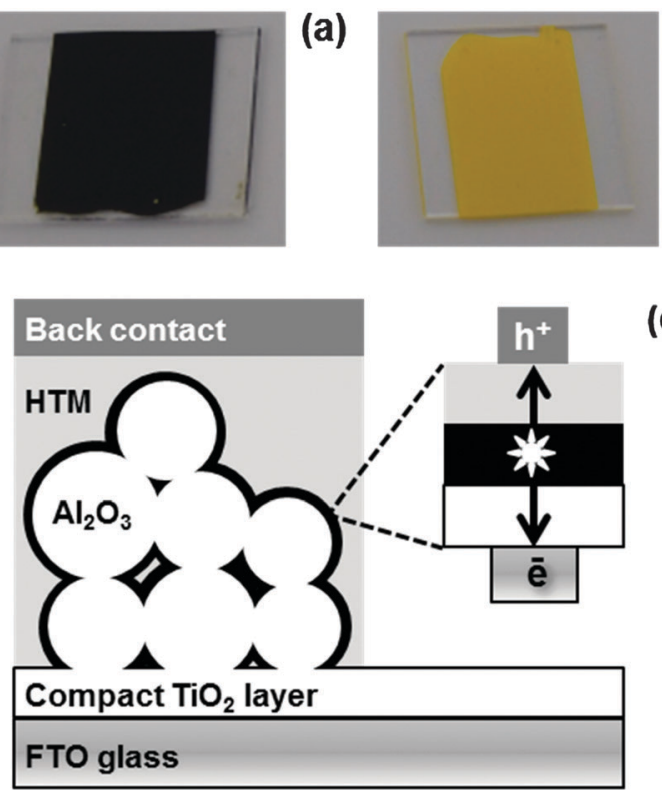

Fig. 1 (a) Semi-perovskite, (b) perovskite intermediate and (c) schematic of perovskite device architecture. again. Conversion to a perovskite phase varies depending on the halides used. For $\mathrm{CH}_{3} \mathrm{NH}_{3} \mathrm{PbI}_{3-x} \mathrm{Cl}_{x}$, an intermediate nonperovskite yellow phase is obtained (Fig. 1b) which only turns black and converts to perovskite after heating at $120{ }^{\circ} \mathrm{C}$ for $50 \mathrm{~min}$ (i.e. standard solution processing conditions). A similar intermediate perovskite complex, has been previously reported by $\mathrm{Wu}$ et $a l .{ }^{13}$ By comparison, the $\mathrm{CH}_{3} \mathrm{NH}_{3} \mathrm{PbI}_{3}$ ink turns black purely by mechanical mixing and before heating at $120{ }^{\circ} \mathrm{C}$ (Fig. 1a). We have defined the pre-heated tri-iodide as "semiperovskite" ink as the XRD data confirm significant amounts of unconverted $\mathrm{PbI}_{2}$ are still present, which then decrease after heating. Finally, $\mathrm{CH}_{3} \mathrm{NH}_{3} \mathrm{PbBr}_{3}$ turns orange on grinding which fully converts and increases in crystallinity on heating (ESI, $\dagger$ Fig. S3). Upon the addition of terpineol, each reaction continues to completion and we believe the terpineol assists in a wet grinding process whereby the size of the $\mathrm{PbX}_{2}$ and $\mathrm{CH}_{3} \mathrm{NH}_{3} \mathrm{X}$ crystals are further reduced and these particles are more intimately mixed enabling intercalation of $\mathrm{CH}_{3} \mathrm{NH}_{3} \mathrm{X}$ into the lead halide lattice to form crystalline perovskite.
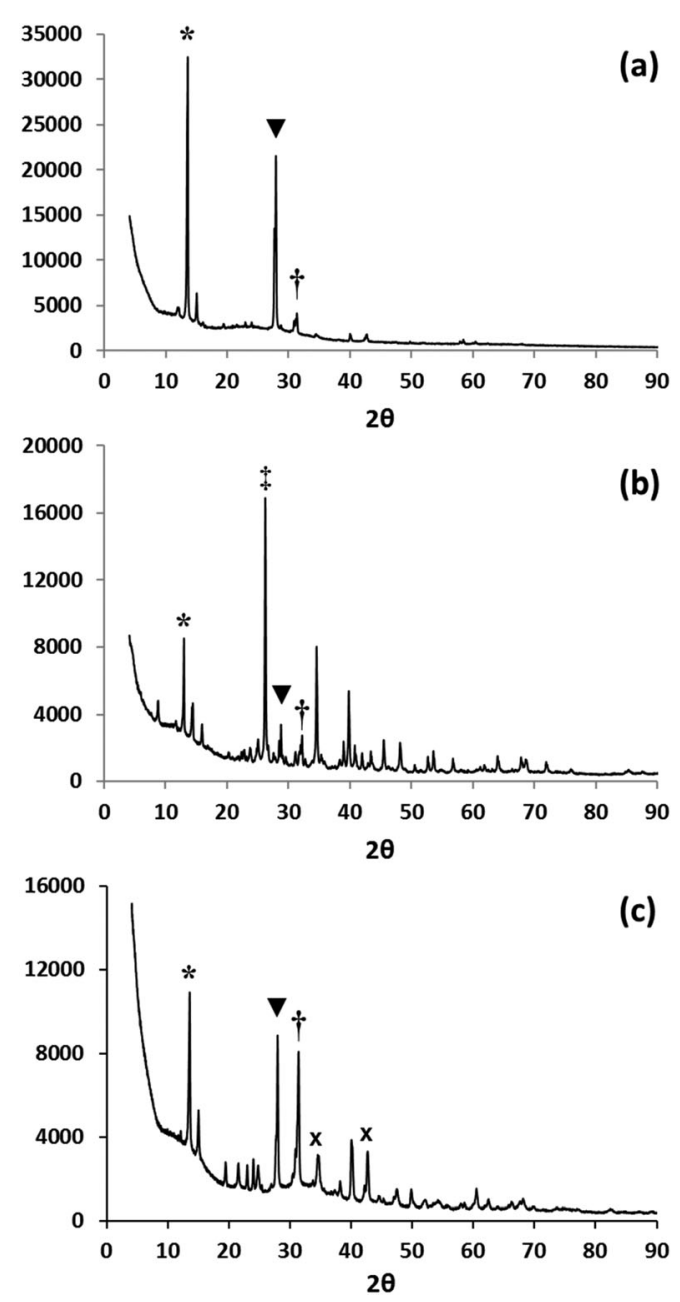

Fig. 2 XRD data of $\mathrm{CH}_{3} \mathrm{NH}_{3} \mathrm{Pbl}_{3}$ films manufactured by (a) solution processing, (b) solid state reaction using $\mathrm{TiO}_{2}$ and (c) deposited on glass from a perovskite ink. * (110), (220), $\dagger(310)$ of perovskite phase, $\times\left(\mathrm{Al}_{2} \mathrm{O}_{3}\right)$, $\neq$ (101) $\mathrm{TiO}_{2}$ diffraction lines. 
X-Ray powder diffraction data show that the solid state reaction between $\mathrm{CH}_{3} \mathrm{NH}_{3} \mathrm{I}$ and $\mathrm{PbI}_{2}$ produces predominantly the $\mathrm{CH}_{3} \mathrm{NH}_{3} \mathrm{PbI}_{3}$ phase with only low intensity peaks observed for $\mathrm{PbI}_{2}$ (Fig. 2b). Unconverted $\mathrm{PbI}_{2}$ has been reported previously in the two-step solution processing method, even when the substrate is heated to $60{ }^{\circ} \mathrm{C}$, to constrain lateral crystal growth. ${ }^{20}$ The $\mathrm{PbI}_{2}$ peaks observed in our work (ground samples) more closely resemble data observed for samples deposited on optimally pre-heated $\left(50{ }^{\circ} \mathrm{C}\right)$ substrates, which is typically done to assist small particle formation and improve coverage. ${ }^{13}$ After grinding in terpineol (Fig. 2c), the (110) peak for the perovskite phase increases in relative intensity, confirming that the solid state reaction continues on further grinding in the solvent. Data from line broadening suggest that the average crystal/domain size is $c a$. $100 \mathrm{~nm}$ which is similar to that typically observed purely for one-step solution processing methods rather than the larger $500 \mathrm{~nm}$ particle sizes observed using the two-step method. ${ }^{17}$ In addition for both ground samples, there is less evidence of preferred orientation (Fig. 2b and c) compared to solution deposited material (Fig. 2a). This is to be expected as the solution deposited samples nucleate and grow directly onto a flat substrate which is heated from below making perpendicular crystal growth much more likely. By comparison, the ground samples nucleate and crystallise onto randomly oriented metal oxide particles so the orientation of their crystal growth will also be randomised.

Photoluminescence (PL) of perovskite films is strongly linked to device efficiency ${ }^{21}$ and so PL microscopy and in situ spectroscopy of perovskite:metal oxide films was carried out to evaluate surface coverage and electron shuttling. The data show that films of doctor bladed $\mathrm{CH}_{3} \mathrm{NH}_{3} \mathrm{PbI}_{3-x} \mathrm{Cl}_{x}$, bar cast $\mathrm{CH}_{3} \mathrm{NH}_{3} \mathrm{PbI}_{3-x} \mathrm{Cl}_{x}$ and $\mathrm{CH}_{3} \mathrm{NH}_{3} \mathrm{PbBr}_{3}$ are all emissive, which suggests they should all be photo-active in PV devices (Fig. 3a-c). As expected, the thicker $7 \mu \mathrm{m}$ doctor bladed $\mathrm{CH}_{3} \mathrm{NH}_{3} \mathrm{PbI}_{3-x} \mathrm{Cl}_{x}$ film (Fig. 3a and f) shows PL intensity which is much greater than that of the equivalent $400 \mathrm{~nm}$ bar cast film (Fig. 3b and f). Interestingly, the intensity of the doctor bladed film is comparable to the solution processed image (Fig. 3e and f). In terms of coverage, two issues need consideration. Firstly, there is the coverage of the mesoporous $\mathrm{Al}_{2} \mathrm{O}_{3}$ film on the substrate and secondly there is the coverage of the perovskite layer on the $\mathrm{Al}_{2} \mathrm{O}_{3}$ surface. For the doctor bladed film, the perovskite coverage on the $\mathrm{Al}_{2} \mathrm{O}_{3}$ surface appears to be consistent whilst the mesoporous $\mathrm{Al}_{2} \mathrm{O}_{3}$ film is much less even. However, there do not appear to be any pin holes in this film which would cause short circuiting in PV devices made from this material. By comparison, the coverage of the perovskite on the $\mathrm{Al}_{2} \mathrm{O}_{3}$ surface in the bar coated film appears less complete although the mesoporous $\mathrm{Al}_{2} \mathrm{O}_{3}$ film itself still appears to be complete. For the analogous bar coated $\mathrm{CH}_{3} \mathrm{NH}_{3} \mathrm{PbBr}_{3}$ sample, greater PL intensity is observed than for the $\mathrm{CH}_{3} \mathrm{NH}_{3} \mathrm{PbI}_{3-x} \mathrm{Cl}_{x}$ sample although at $\lambda$ ca. $540 \mathrm{~nm}$ reflecting the larger band gap for the tribromide perovskite. Here, the perovskite coverage on $\mathrm{Al}_{2} \mathrm{O}_{3}$ seems fairly complete although some areas seem brighter than others suggesting variable particle sizes of perovskite crystals have been deposited (Fig. 3c). To further study scaffold coverage, a $\mathrm{TiO}_{2}$-based $\mathrm{CH}_{3} \mathrm{NH}_{3} \mathrm{PbI}_{3}$ paste was bar coated onto a glass substrate. The maximum PL (a)

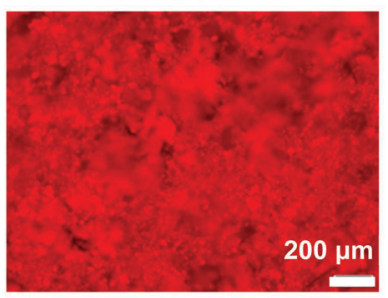

(c)

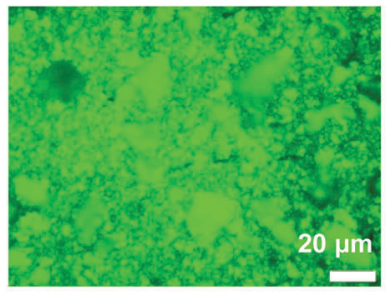

(e)

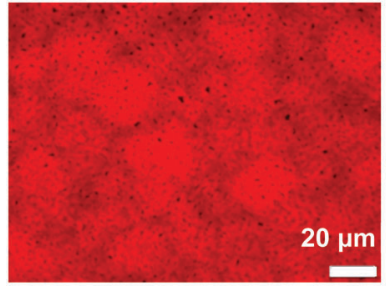

(b)

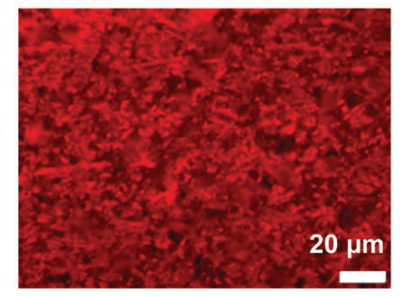

(d)

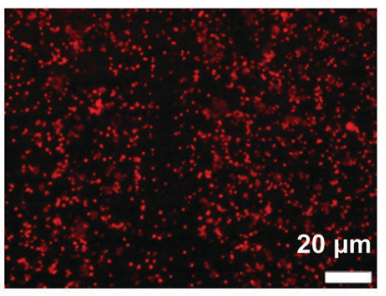

(f)

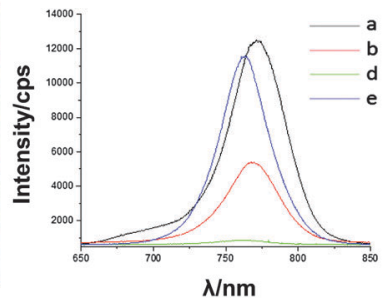

Fig. 3 Photoluminescence images of films of (a) $7 \mu \mathrm{m}$, 2-step, doctor bladed $\mathrm{CH}_{3} \mathrm{NH}_{3} \mathrm{Pbl}_{3-x} \mathrm{Cl}_{x}$ (b) $4 \mu \mathrm{m}$ wet thickness, bar cast sequential $\mathrm{CH}_{3} \mathrm{NH}_{3} \mathrm{Pbl}_{3-x} \mathrm{Cl}_{x}$, (c) $4 \mu \mathrm{m}$ wet thickness, bar cast $\mathrm{CH}_{3} \mathrm{NH}_{3} \mathrm{PbBr}_{3}$, (d) $4 \mu \mathrm{m}$ wet thickness, bar cast, one step $\mathrm{TiO}_{2}-\mathrm{CH}_{3} \mathrm{NH}_{3} \mathrm{Pbl}_{3}$, (e) spun coated solution processed $\mathrm{CH}_{3} \mathrm{NH}_{3} \mathrm{Pbl}_{3-x} \mathrm{Cl}_{x}$ and $(\mathrm{f})$ intensity vs. $\lambda$ for selected $\mathrm{PL}$ image.

intensity for this sample is $c a .600 \mathrm{cps}$ compared to $c a .12000$ cps for the doctor bladed and ca. 6000 cps bar coated $\mathrm{CH}_{3} \mathrm{NH}_{3} \mathrm{PbI}_{3-x} \mathrm{Cl}_{x}$ films. Firstly, this suggests that the perovskite films formed can effectively inject into an electrically-conducting scaffold whilst the PL mapping (Fig. 3d) of $\mathrm{TiO}_{2}$-based perovskite ink shows areas of low PL intensity across the film surface. As the films are not under load, we expect emission to be faster than injection so the low emission for this film may reflect poor coverage or lower stability of the $\mathrm{CH}_{3} \mathrm{NH}_{3} \mathrm{PbI}_{3}$ on $\mathrm{TiO}_{2}$. By comparison, the more uniform emission across the perovskite: $\mathrm{Al}_{2} \mathrm{O}_{3}$ films confirms better coverage and perovskite stability and could also suggest lower losses at grain boundaries or crystal interfaces where emission might be quenched. Ultimately, assuming that more emission relates to more potential charge extraction in a PV device under load and given the need for PV devices to possess lifetimes of many years this suggests $\mathrm{Al}_{2} \mathrm{O}_{3}$ scaffolds should be preferable to $\mathrm{TiO}_{2}$. Furthermore, perovskites which have been solution processed onto metal oxide scaffolds exhibit slightly blueshifted emission (760 nm vs. $750 \mathrm{~nm}$ ) as a result of confined growth within mesoporous films. ${ }^{22,23}$ Fig. $3 f$ shows that the PL peaks of the ink-based films are similarly blue shifted compared to the solution processed film. This suggests that the perovskite crystals from perovskite inks are similar in size to those grown inside scaffolds, using standard solution processed methods 


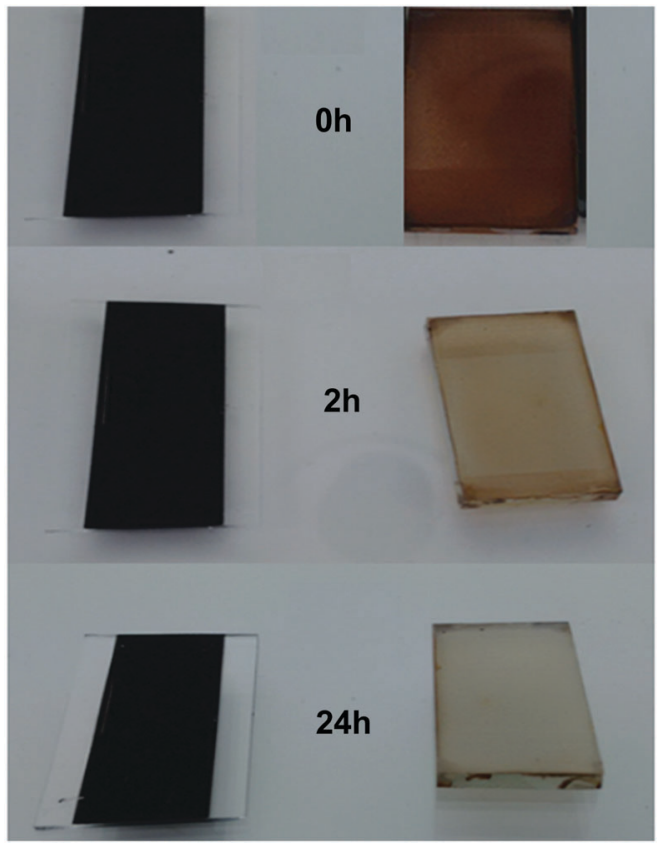

Fig. 4 (left) Bar-cast $\mathrm{CH}_{3} \mathrm{NH}_{3} \mathrm{Pbl}_{3}: \mathrm{Al}_{2} \mathrm{O}_{3}$ perovskite ink and (right) spin coated, solution processed $\mathrm{CH}_{3} \mathrm{NH}_{3} \mathrm{Pbl}_{3}$ films vs. time.

(i.e. typically $<100 \mathrm{~nm}$ ). Perovskite film morphology has also been investigated by SEM (ESI, $\dagger$ Fig. S5-S8) which shows the best perovskite coverage for $\mathrm{CH}_{3} \mathrm{NH}_{3} \mathrm{PbBr}_{3}$ ink in line with the higher intensity PL data for this film.

The lifetime of the perovskite films has also been studied (Fig. 4). The data show that $\mathrm{Al}_{2} \mathrm{O}_{3}$-based films exhibit significantly better resistance to atmospheric exposure (air, humidity, light) than solution processed films. We have observed that the first stage of humidity-driven perovskite degradation involves phase separation into $\mathrm{PbX}_{2}$ and $\mathrm{CH}_{3} \mathrm{NH}_{3} \mathrm{X}$ but that both materials remain on the surface. Hence, in the early stages of degradation, the process can be reversed by heating at $100{ }^{\circ} \mathrm{C}$. However, this reversibility is only possible when the $\mathrm{PbX}_{2}$ and $\mathrm{CH}_{3} \mathrm{NH}_{3} \mathrm{X}$ are proximally located on the surface. As further phase separation occurs with time, this process becomes irreversible by heating. However, it can be reversed by drying, grinding and heating to re-mix the $\mathrm{PbX}_{2}+\mathrm{CH}_{3} \mathrm{NH}_{3} \mathrm{X}$. Here, we believe that the stabilising influence of the $\mathrm{Al}_{2} \mathrm{O}_{3}$ is to slow the rate of phase separation and, in doing so, effectively to shift the equilibrium $\left(\mathrm{PbX}_{2}+\right.$ $\mathrm{CH}_{3} \mathrm{NH}_{3} \mathrm{X} \leftrightarrow \mathrm{CH}_{3} \mathrm{NH}_{3} \mathrm{PbX}_{3}$ ) towards perovskite. Interestingly, $\mathrm{Al}_{2} \mathrm{O}_{3}$ capping layers on the perovskite absorber layer have also been reported as moisture barriers. ${ }^{10}$ TGA data (ESI, $\dagger$ Fig. S11 and S12) suggest that some terpineol may remain after heating but that this reduces with increasing temperature and/or time. If terpineol acts as a solvent of crystallization it should slow $\mathrm{H}_{2} \mathrm{O}$ ingress but residual solvent is not expected to limit PV efficiency as it has been reported that small amounts of inert media (e.g. $\mathrm{PEG}^{24}$ ) do not limit device performance. However, removing all terpineol does not reduce film lifetime (ESI, $\dagger$ Fig. S12) suggesting surface perovskite: $\mathrm{Al}_{2} \mathrm{O}_{3}$ interactions may enhance film stability.

In summary, we have demonstrated that photo-active, organolead perovskites can be prepared by solid state reactions onto $\mathrm{Al}_{2} \mathrm{O}_{3}$ scaffolds producing materials with enhanced stability. Whilst this resolves key processing limitations by negating the need for toxic or hygroscopic solvents such as DMF, GBL or DMSO, ${ }^{9}$ this approach also makes the synthesis of other (e.g. lead-free) organometallic perovskites much simpler as it avoids complex solvent engineering issues $^{25}$ or complex solvent-solvent extraction techniques. ${ }^{26}$ In addition, using solid state reactions means that all the raw materials end up in the product which makes it easier to add trace components. Also the printing of pre-made perovskite inks is easily scalable whilst solution-based spin coating is not and the vast majority of precursor solutions are spun away making compositional control very difficult.

\section{References}

1 M. M. Lee, J. Teuscher, T. Miyasaka, T. N. Murakami and H. J. Snaith, Science, 2012, 338, 643.

2 L. Etgar, P. Gao, Z. Xue, Q. Peng, A. K. Chandriran, B. Liu, M. K. Nazeeruddin and M. Grätzel, J. Am. Chem. Soc., 2012, 134, 17396.

3 W. S. Yang, J. H. Noh, N. J. Jeon, Y. C. Kim, S. Ryu, J. Seo and S. I. Seok, Science, 2015, 348, 1234.

4 T. Salim, S. Sun, Y. Abe, A. Krishna, A. C. Grimsdale and Y. M. Lam, J. Mater. Chem. A, 2015, 3, 8943.

5 M. Liu, M. B. Johnson and H. J. Snaith, Nature, 2013, 501, 395.

6 (a) H.-R. Xia, W.-T. Sun and L.-M. Peng, Chem. Commun., 2015, 51, 13787; (b) C. Muthu, S. R. Nagamma and V. C. Nair, RSC Adv., 2014, 4, 55908.

7 Y. Jin and G. Chumanov, ACS Appl. Mater. Interfaces, 2015, 7, 12015.

8 N. Yantara, D. Sabba, F. Yanan, J. M. Kadro, T. Moehl, P. P. Boix, S. Mhaisalkar, M. Grätzel and C. Grätzel, Chem. Commun., 2015, 51, 4603.

9 P. J. Holliman, A. Connell, E. W. Jones, S. Ghosh, L. Furnell and R. J. Hobbs, Mater. Res. Innovations, 2016, 19, 508.

10 J. Burschka, N. Pellet, S. J. Moon, R. Humphry-Baker, P. Gao, M. K. Nazeeruddin and M. Grätzel, Nature, 2013, 499, 316.

11 S. Luo and W. A. Daoud, J. Mater. Chem. A, 2015, 3, 8992.

12 L. C. Schmidt, A. Pertega, S. Gonzalez-Carrero, O. Malinkiewicz, S. Agouram, G. M. Espallargas, H. J. Bolink, R. E. Galian and J. PerezPrieto, J. Am. Chem. Soc., 2014, 136, 850.

13 Y. Wu, A. Islam, X. Yang, C. Qin, J. Liu, K. Zhang, W. Peng and L. Han, Energy Environ. Sci., 2014, 7, 2934.

14 M. J. Carnie, C. Charbonneau, M. L. Davies, J. Troughton, T. M. Watson, K. Wojciechowski, H. Snaith and D. A. Worsley, Chem. Commun., 2013, 49, 7893.

15 Y. Deng, E. Peng, Y. Shao, Z. Xiao, Q. Dong and J. Huang, Energy Environ. Sci., 2015, 8, 1544.

16 P. J. Holliman, D. K. Muslem, E. W. Jones, A. Connell, M. L. Davies, C. Charbonneau, M. J. Carnie and D. A. Worsley, J. Mater. Chem. A, 2014, 2(29), 11134.

17 J. M. Ball, M. M. Lee, A. Hey and H. J. Snaith, Energy Environ. Sci., 2013, 6, 1739.

18 N. Espinosa, L. Serrano-Luján, A. Urbino and F. C. Krebs, Sol. Energy Mater. Sol. Cells, 2015, 137, 303.

19 Q. Chen, H. Zhou, Y. Fang, A. Z. Stieg, T.-B. Song, H.-H. Wang, X. Xu, Y. Liu, S. Lu, J. You, P. Sun, J. McKay, M. S. Goorsky and Y. Yang, Nat. Commun., 2015, 6, 7269.

20 H.-S. Ko, J.-W. Lee and N.-G. Park, J. Mater. Chem. A, 2015, 3, 8808.

21 F. Deschler, M. Price, S. Pathak, L. E. Klintberg, D.-D. Jarausch, R. Higler, S. Hüttner, T. Leitjens, S. D. Stranks, H. J. Snaith, M. Atatüre, R. T. Phillips and R. H. Friendm, J. Phys. Chem. Lett., 2014, 5, 1421.

22 M. De Bastiani, V. D'Innocenzo, S. D. Stranks, H. J. Snaith and A. Petrozza, APL Mater., 2014, 2, 081509.

23 V. D'Innocenzo, G. Grancini, M. J. P. Alcocer, A. R. S. Kandada, S. D. Stranks, M. M. Lee, G. Lanzani, H. J. Snaith and A. Petrozza, Nat. Commun., 2014, 5, 3586.

24 C.-Y. Chang, C.-Y. Chu, Y.-C. Huang, S.-Y. Chang, C.-A. Chen, C.-Y. Chao and W.-F. Su, ACS Appl. Mater. Interfaces, 2015, 7, 4955.

25 N.-J. Jeon, J.-H. Noh, Y.-C. Kim, W.-S. Yang, S. Ryu and S.-I. Seok, Nat. Mater., 2014, 13, 897.

26 Y. Zhou, M. Yang, W. Wu, A. L. Vasiliev, K. Zhu and N. P. Padture, J. Mater. Chem. A, 2015, 3, 8179. 